\title{
PELAKSANAAN PENDAFTARAN TANAH ULAYAT KAUM MELALUI PROGRAM PENDAFTARAN TANAH SISTEMATIS LENGKAP DI KECAMATAN BUNGUS TELUK KABUNG
}

\author{
Feronika \\ Universitas Andalas, feronika324@gmail.com \\ Azmi Fendri \\ Universitas Andalas, azmi_fendri@gmail.com \\ Yulia Mirawati \\ Universitas_Andalas,yulia_mirawati@gmail.com
}

\begin{abstract}
Ulayat land is a land that is acquired from generation to generation whose control and utilization are regulated by the Mamak. Waris Head. This is all obtained without correspondence or in Writing, only by knowing the boundaries naturally with someone else's land. In Padang City, especially in Bungus Teluk Kabung Subdistrict, most of the existing property is customary land. Ulayat land is used for the benefit of its people. The government is obliged to bold land registration in the entire territory of the Republic of Indonesia. One of the methods adopted by the Ministry of Agrarian and Spatial Planning / National Land Agency is through the Complete Systematic Land Registration Implementation Acceleration program as stipulated in the Regulation of the Minister of Agrarian and Spatial Planning / Head of the Republic of Indonesia National Land Agency Number 12 of 2017 concerning Acceleration of Complete Systematic Land Registration, which was carried out in Bungus Teluk. Kabung Subdistrict which had a target of 1,100 fields. The formulation of the problem in this Writing is 1 . How is the implementation of community ulayat land registration through the Complete Systematic Land Registration program in Bungus Subdistrict Teluk. Kabung. 2. What obstacles were encountered in the implementation of the record of communal ulayat land through the Complete Systematic Land Registration program in Bungus Subdistrict Teluk. Kabung. And in this Writing the author uses a sociological juridical approach. Based on the research conducted by the author, the implementation of the registration of ulayat land of the people through the Complete Systematic Land Registration Program in Bungus District Teluk. Kabung. It is challenging to implement and does not achieve this target because there are some obstacles in the implementation of the ulayat land registration of the people so that the ulayat land of the community cannot be registered with the Land Office. Constraints arise include subject, namely whose name certificate recorded in the name of the Mamak Chief Heir, on behalf of one member of the community or in the name of Mamak the Head of Waris along with members of the city because in most fields many register on behalf of one member the people without being noticed by Mamak To Waris and other members of the people. Another obstacle is the absence of the Mamak Waris Head and Kerapatan Adat Nagari in the land registration process.
\end{abstract}

Keywords: Complete Systematic Land Registration, Land, Ulayat Kaum.

\begin{abstract}
Abstrak
Tanah ulayat kaum merupakan tanah yang diperoleh secara turun temurun yang penguasaan dan pemanfaatanya diatur oleb Mamak. Kepala Waris. Ini semuanya diperoleh tanpa surat menyurat atan secara tertulis, hanya dengan mengetahui batas-batas secara alami dengan tanah milik orang lain. Di Kota Padang khususnya di Kecamatan Bungus Teluk Kabung sebagian besar tanah yang ada merupakan tanah ulayat. Tanah ulayat dipergunakan untuk kepentingan kaumnya. Dalam rangka mewnjudkan kehadiran Negara di bidang pertanahan dengan memberikan jaminan kepastian bukum Hak. Atas Tanah sebagai bukti bak kepemilikan sebagaimana diamanatkan dalam Pasal 19 UUPA, pemerintab berkewajiban menyelenggarakan pendaftaran tanah di seluruh wilayah Republik. Indonesia. Salab satu cara yang ditempub Kementerian Agraria dan Tata Ruang/Badan Pertanahan Nasional adalah melalui program
\end{abstract}


Percepatan Pelaksanaan Pendaftaran Tanah Sistematis Lengkap sebagaimana diatur dalam Peraturan Menteri Agraria dan Tata Ruang/Kepala Badan Pertanaban Nasional Republik Indonesia Nomor 12 Tabun 2017 tentang Percepatan Pelaksanaan Pendaftaran Tanab Sistematis Lengkap, yang dilaksanakan di Kecamatan Bungus Teluk Kabung yang mendapat target 1.100 bidang. Rumusan masalah dalam Penulisan ini adalah 1. Bagaimana pelaksanaan pendaftaran tanah ulayat kaum melalui program Pendaftaran Tanah Sistematis Lengkap di Kecamatan Bungus Teluk Kabung. 2. Kendalakendala apa yang dihadapi dalam pelaksanaan pendaftaran tanah ulayat kaum melalui program Pendaftaran Tanah Sistematis Lengkap di Kecamatan Bungus Teluk Kabung. Dan dalam penulisan ini penulis menggunakan metode pendekatan yuridis sosiologis. Berdasarkan penelitian yang penulis lakukan, pelaksanaan pelaksanaan pendaftaran tanah ulayat kaum melalui Program Pendaftaran Tanah Sistematis Lengkap di Kecamatan Bungus Teluk Kabung. sulit dilaksanakan dan tidak mencapai target hal ini karena ditemui beberapa kendala-kendala dalam pelaksanaan pendaftaran tanah ulayat kaum tersebut sehingga tanah ulayat kaum belum bisa didaftarkan ke Kantor Pertanahan. Kendala-kendala yang timbul diantaranya adalah mengenai subyeknya yaitu atas nama siapa sertipikat itu didaftarkan apakah atas nama Mamak Kepala Waris, atas nama salah satu anggota kaum atau atas nama Mamak Kepala Waris beserta anggota kaum karena pada umumnya dilapangan banyak yang mendaftarkan atas nama salah seorang anggota kaum tanpa diketahui oleh Mamak Kepada W aris beserta anggota kaum lainya. Kendala yang lainya adalah tidak dilibatkannya Mamak Kepala Waris, dan Kerapatan Adat Nagari dalam proses pendaftaran tanah tersebut.

Kata Kunci: Pendaftaran Tanah Sistematis Lengkap, Tanah, Ulayat Kaum.

\section{PENDAHULUAN}

Negara Kesatuan Republik Indonesia terdiri dari kepualuan dengan berbagai suku bangsa yang mempunyai adat istiadat dan agama yang berlainan sebagai warisan budaya bangsa Indonesia yang hidup dan berkembang ditengah pergaulan dunia. Warisan tersebut terus berkembang sepanjang masa sebagai warisan untuk anak cucu bangsa Indonesia dikemudian hari. Salah satu kebudayaan daerah yang ada dalam Negara Kesatuan Republik Indonesia adalah Adat Alam Minangkabau yang dianut dan dikembangkan oleh masyarakat Minangkabau sejak dahulu sampai sekarang. Ajaran Adat Alam Minangkabau termasuk ajaran adat yang mempunyai keistimewaan tersendiri.

Masyarakat Adat Minangkabau pada dasarnya terikat dalam satu garis keturunan yang ditarik menurut garis keturunan Ibu yang disebut Matrilineal. Karena keturunan itu hanya dihitung dan ditelusuri menurut garis keturunan Ibu saja.Sistem kekerabatan masyarakat Minang ini masih dipegang teguh oleh masyarakat keturunan Minang sampai sekarang ini.

Pada dasarnya sistem matrilineal bukanlah untuk mengangkat atau memperkuat peranan perempuan, tetapi sistem itu dikukuhkan untuk menjaga, melindungi harta pusaka suatu kaum dari kepunahan, baik rumah gadang, tanah pusaka, dan sawah, ladang. Masyarakat hukum adat zaman dahulu yang masih belum mengenal arti hukum Agraria, pada waktu itu berlaku ketentuan bahwa siapa yang pertama kali membuka suatu lahan dan mendudukinya, maka dialah yang dianggap menjadi pemilik tanah tersebut.

Dalam hal ini untuk pembuktian kepemilikan tanah tidak diperlukan surat-surat secara tertulis, tetapi cukup adanya pengakuan secara lisan dari masyarakat setempat bahwa benar tanah yang bersangkutan telah lama diduduki oleh orang yang bersangkutan sehingga orang tersebut dianggap sebagai pemiliknya. Pada masyarakat hukum adat dikenal sebuah istilah yang disebut "Hak Ulayat".

Hak Ulayat adalah kewenangan yang menurut hukum adat dipunyai oleh masyarakat hukum adat tertentu atas wilayah tertentu yang merupakan lingkungan hidup para warganya untuk mengambil manfaat dari sumber daya alam termasuk tanah dalam wilayah tersebut bagi kelangsungan hidup dan kehidupanya yang timbul dari hubungan secara lahiriah dan 
bathiniah, turun temurun dan tidak terputus antara masyarakat hukum adat tersebut dengan wilayah yang bersangkutan.

Di Sumatera Barat (Minangkabau) khususnya kota Padang sebagian besar tanah yang ada merupakan tanah ulayat. Tanah ulayat dahulunya diperoleh dengan cara penunjukan dari nenek moyang karena mereka telah lama menikmati dan mengolah tanah tersebut atau diperoleh dari pemberian karena sesuatu yang telah dilakukan. Ini semuanya diperoleh tanpa surat menyurat atau secara tertulis, hanya dengan mengetahui batas-batas secara alami dengan tanah milik orang lain.

Kepastian hak atas tanah ulayat kaum yang berlaku secara turun temurun berpegang pada Ranji (Silsilah Keturunan) suatu kaum. Ranji tersebut akan disampaikan oleh mamak kepada kemenakan yang dianggap berperan sebagai pimpinan suatu kaum. Tanah pada penguasaanya haruslah berfungsi sosial dan mempunyai asas kekeluargaan.

Dalam sistem kekerabatan minangkabau, ranji tersebut dibuat dengan menarik garis keturunan ibu, garis keturunan ini juga mempunyai arti pada pewarisan harta pusaka. Dalam pengertian umum harta pusaka ialah sesuatu yang bersifat material yang ada pada seseorang yang mati yang dapat beralih kepada orang lain semata akibat kematianya itu. ${ }^{1}$ Pewarisan harta itu hanyalah dalam arti pemanfaatanya untuk penghidupan. Hasilnya dapat dipergunakan untuk kebutuhan seharihari, sedangkan pemindahan hak ditentukan oleh syarat-syarat tertentu. ${ }^{2}$

Harta pusaka terbagi dua macam yaitu harta pusaka tinggi dan harta pusaka rendah. Harta pusaka tinggi adalah segala harta pusaka

1 Amir Syarifuddin, Pelaksanaan Hukum Kewarisan Islam Dalam Lingkungan Adat Minangkabau, (Jakarta: Gunung Agung , 1984). 212

2 Boestami, Sjafnir Abu Naim dan Rosnida M Nur LC, Kedudukan dan Peranan W anita Dalam Kebudayaan Suku Bangsa Minangkabau, (Padang: Esa Padang, 1992). 40 yang diwarisi secara turun temurun sesuai dengan pantun sebagai berikut: ${ }^{3}$

Biriek-birike tabang ka sasak

Dari sasak turun ke halaman

Dari niniek turun ka mamak.

Dari mamak turun ka kamanakan

Birik- birik terbang ke sasak

Dari sasak turun ke halaman

Dari ninik turun kepada mamak

Dari mamak turun kepada kemenakan

Proses pemindahan kekuasaan atas harta pusaka ini dari mamak kepada kemenakan dalam istilah adat disebut juga dengan "pusako basalin". Bagi harta pusaka tinggi berlaku ketentuan adat sebagai berikut:

Tajua indak dimakan bali

Tasando indak dimakan gadai

Terjual tidak bisa dibeli

Agunan tidak bisa digadai

Hal ini berarti bahwa harto pusako tinggi tidak boleh dijual. Oleh karena itu pusako tinggi sesungguhnya bukan diwariskan dari mamak kepada kemenakan tetapi dari uo (nenek) kepada mande (ibu) kita dan dari ibu kita kepada saudara perempuan kita.

Harta pusaka rendah adalah segala harta hasil pencaharian dari bapak bersama ibu (orang tua kita) selama ikatan perkawinan, ditambah dengan pemberian mamak dan tungganai kepada kemenakanya dari hasil pencaharian mamak dan tungganai itu sendiri. ${ }^{4}$ Menurut adat Minangkabau, harta yang diperoleh suatu kaum atau salah seorang anggota kaum dengan cara apapun, sesudah diturunkan satu kali bergabung dengan harta yang diterimanya dari generasi sebelumnya, maka setiap angkatan generasi terjadilah percampuran harta, sehingga pihak yang menerima harta tersebut dikemudian hari tidak

\footnotetext{
${ }^{3}$ Amir MS, Adat Minangkabau Pola dan Tujuan Hidup Orang Minang, (Jakarta: Mutiara Sumber Widya, 1997). 93

${ }^{4}$ Ibid. 94
} 
tahu lagi asal usul harta tersebut. Harta yang seperti itulah kemudian akan berubah menjadi harta pusaka tinggi. ${ }^{5}$

Hukum adat Minangkabau menyatakan tidak ada sejengkal tanahpun yang tidak ada berpunya, berapapun luasnya ada penguasanya, baik oleh suatu kaum, suku maupun suatu nagari yang disebut dengan tanah ulayat ataupun oleh perorangan yang merupakan hak pribadi. Minangkabau sebagai salah satu persekutuan hukum atau masyarakat hukum adat secara garis besar mengenal 3 (tiga) macam persekutuan masyarakat yaitu Nagari, Suku dan Kaum.

Nagari menurut Pasal 1 huruf g Peraturan Daerah (Perda) Sumatera Barat No. 9 dan diubah Perda No. 2 tahun 2007 tentang Pokok-Pokok Pemerintahan Nagari menetapakan Nagari adalah kesatuan masyarakat hukum adat didalam daerah Provinsi Sumatera Barat yang terdiri dari himpunan beberapa suku yang mempunyai wilayah yang tertentu batas-batasnya mempunyai harta kekayaan dan mengurus rumah tangganya dan memilih pimpinan pemerintahanya.

Pada Pasal 33 ayat (3) UUD 1945 menjadi dasar tentang pemanfaatan dan pendayagunaan tanah tersebut, dimana dalam pasal ini menyatakan bahwa "Bumi, air dan kekayaan alam yang terkandung didalamnya dikuasai oleh negara dan dipergunakan sebesar-besarnya untuk kemakmuran rakyat".

Pasal tersebut merupakan landasan konstitusional bagi Undang-Undang Pokok Agraria (UUPA) yaitu Undang-Undang Nomor 5 Tahun 1960 pada Pasal 2 ayat (1) UUPA menyatakan bahwa "Kekuasaan mengatur pengelolaan bumi,air dan ruang angkasa termasuk kekayaaan alam yang terkandung didalamnya pada tingkatan tertinggi dikuasai oleh negara sebagai organisasi kekuasaan seluruh rakyat. Dalam hal

\footnotetext{
${ }^{5}$ Ibid
}

ini diketahui bahwa negara hanya sebagai penguasa yang bertujuan untuk mengurus,mengatur dan melindungi.

$$
\text { Undang-undang Pokok Agraria }
$$
sebagai ketentuan yang mengatur masalah tanah seluruh wilayah Republik Indonesia, menyatakan negara sebagai penguasa atas seluruh wilayah Republik Indonesia. Penguasaan dari negara ini merupakan penguasaan dalam konsep publik karena bersifat mengatur, lebih rinci dapat dilihat dalam Pasal 2 ayat (2), Hak menguasai dari Negara termasuk dalam ayat 1 pasal ini memberi wewenang untuk:

1. Mengatur dan menyelenggarakan peruntukan, penggunaan, persediaan, dan pemeliharaan, bumi, air dan ruang angkasa tersebut.

2. Menentukan dan mengatur hubunganhubungan hukum antara orang-orang dengan bumi, air dan ruang angkasa.

3. Menentukan dan mengatur hubungan hukum antara orang-orang dan perbuatanperbuatan hukum yang mengenai bumi, air, dan runag angkasa.

Dasar hak menguasai dari Negara sebagaimana yang dimaksud dalam Pasal 2 ditentukan adanya macam-macam hak atas permukaan bumi yang disebut tanah yang dikemas dalam dua Pasal yakni Pasal 6 UUPA dan Pasal 3 UUPA. Hak atas permukaan bumi yang disebut dengan tanah tersebut dinyatakan sebagai hak atas tanah, yang dapat diberikan kepada dan dipunyai oleh orang-orang baik sendiri maupun bersama-sama dengan orang lain serta badan-badan hukum. Hak atas tanah yang dapat diberikan kepada orang-orang secara bersama-sama memunculkan konsep individual hak jika kebersamaan itu kebersamaan yang dapat dibagi-bagi.

Di samping itu ada hak kebersamaan yang tidak dapat dibagi-bagi, hak inilah yang disebut dengan hak komunal atau hak ulayat. Hak ulayat ini merupakan hak asli bangsa 
Indonesia dengan berbagai sebutan sesuai dengan hak ulayat . Jenis apapun dari hak atas tanah tersebut harus tampil dengan pembatasan fungsi sosial (Pasal 6 UUPA).

Meskipun secara tegas UUPA mengakui adanya Hak ulayat (Pasal 3), namun tidak ditindaklanjuti dengan ketentuan organik sehingga dalam prakteknya sering menimbulkan konflik. Hal ini terutama dikaitkan dengan keinginan untuk memberikan kepastian hukum dan kepastian hak atas tanah melalui pendaftaran tanah (Pasal 19 UUPA). Didalam UUPA Untuk memberikan kepastian hukum menyangkut hak atas tanah maka dilakukan pendaftaran diseluruh Indonesia.

Negara bertugas menyelenggarakan pendaftaran tanah yang dilaksanakan oleh pemerintah bagi kepentingan rakyat dalam upaya memberikan jaminan kepastian hukum dibidang pertanahan. Sebagian kegiatanya yang berupa pengumpulan data fisik tanah yang haknya didaftar, hasilnya memerlukan pengesahan pejabat pendaftaran yang berwenang karena akan digunakan sebagai alat bukti yang dipunyai seseorang atas suatu obyek tanah.

Jaminan kepastian hukum ini tercantum dalam ketentuan Pasal 19 ayat (1) Undang-Undang Pokok Agraria dinyatakan bahwa yang mengadakan pendaftaran tanah di seluruh wilayah Republik Indonesia adalah Pemerintah. ${ }^{6}$ Pasal 19 ayat (3) UUPA menyebutkan bahwa pendaftaran tanah diselenggarakan dengan mengingat keadaan negara dan masyarakat, keperluan lalu lintas sosial-ekonomi serta kemungkinan penyelenggaraanya, menurut pertimbangan Mentri Agraria. ${ }^{7}$ UUPA menetapkan bahwa bagi rakyat tidak mampu dibebaskan dari biaya pendaftaran tanah. Hal ini ditegaskan dalam pasal 19 ayat (4) yaitu " Dalam Peraturan Pemerintah diatur biaya-biaya yang

6 Urip Santoso, Hukum Agraria, Jakarta: Kencana Prenada Media Group, 2012). 295

${ }^{7}$ Ibid. 296 bersangkutan dengan pendaftaran tanah yang termaksud dalam ayat (1) diatas, dengan ketentuan bahwa rakyat yang tidak mampu dibebaskan dari pembayaran biaya-biaya tersebut". ${ }^{8}$

Pendaftaran tanah harus dilaksanakan seteliti mungkin dengan menghormati hak-hak adat daerah atau desa. Karena pentingnya pendaftaran tanah tersebut, maka baik petugas pendaftaran maupun masyarakat diminta untuk saling membantu agar tercapai apa yang menjadi tujuan pokok dari pendaftaran tanah itu sendiri.

Dalam rangka mewujudkan kehadiran Negara di bidang pertanahan dengan memberikan jaminan kepastian hukum Hak Atas Tanah sebagai bukti hak kepemilikan sebagaimana diamanatkan dalam Pasal 19 Undang-Undang Nomor 5 Tahun 1960 tentang Peraturan Dasar Pokok-Pokok Agraria (UUPA), pemerintah berkewajiban menyelenggarakan pendaftaran tanah di seluruh wilayah Republik Indonesia. Oleh karena itu dirasa perlu untuk dilakukan percepatan pendaftaran tanah untuk mengejar persentase tanah terdaftar yang masih di bawah 50\% hingga saat ini. Salah satu cara yang ditempuh Kementerian Agraria dan Tata Ruang/Badan Pertanahan Nasional adalah melalui program Percepatan Pelaksanaan Pendaftaran Tanah Sistematis Lengkap sebagaimana diatur dalam Peraturan Menteri Agraria dan Tata Ruang/Kepala Badan Pertanahan Nasional Republik Indonesia Nomor 12 Tahun 2017 tentang Percepatan Pelaksanaan Pendaftaran Tanah Sistematis Lengkap .

Dalam Pasal 1 angka 2 Peraturan Menteri ini yang dimaksud dengan Pendaftaran Tanah Sistematis Lengkap yang selanjutnya disingkat PTSL adalah kegiatan pendaftaran tanah untuk pertama kali yang

\footnotetext{
8 Ibid.

9 Mujiono, Hukum Agraria, (Yogyakarta: Liberty, 1992). 24
} 
dilakukan secara serentak bagi semua obyek pendaftaran tanah di seluruh wilayah Republik Indonesia dalam satu wilayah desa/kelurahan atau nama lainnya yang setingkat dengan itu, yang meliputi pengumpulan dan penetapan kebenaran data fisik dan data yuridis mengenai satu atau beberapa obyek pendaftaran tanah untuk keperluan pendaftarannya.

Program Pendaftaran Tanah Sistematis Lengkap (PTSL) menargetkan seluruh jengkal tanah di Indonesia telah terdaftar pada tahun 2025. Di Sumatera Barat, PTSL tahun ini menyasar 65.000 pendaftaran sertifikat, yang diawasi pelaksanaannya oleh Kantor Wilayah Agraria dan Tata Ruang/Badan Pertanahan Nasional (Kanwil ATR/BPN) Sumatera Barat. ${ }^{10}$ Kota Padang mendapatkan kuota PTSL sebanyak 20.000 bidang sertifikat tanah, dibagi di dua kecamatan yaitu Kecamatan Bungus Teluk Kabung dan Kecamatan Lubuk Begalung (Lubeg) yang masing-masing kecamatan mendapatkan 10.000 bidang sertifikat $\operatorname{tanah}^{11}$

Kecamatan Bungus Teluk Kabung berada dalam jarak $12 \mathrm{KM}$ dari pusat kota dan berbatasan langsung dengan Kabupaten Pesisir Selatan dengan Luas 100,78 $\mathrm{KM}^{2}$, yang tediri dari 6 Kelurahan diantaranya :

1. Kelurahan Bungus Barat

2. Kelurahan Bungus Selatan

3. Kelurahan Bungus Timur

4. Kelurahan Teluk Kabung Selatan

5. Kelurahan Teluk Kabung Tengah

6. Kelurahan Teluk Kabung Utara

Penggunaan lahan untuk perkebunan sangat dominan di Kecamatan ini yang meliputi 27,73 persen dari total luas wilayah Kecamatan. Sebahagian besar areal

10 //harianhaluan.com/mobile/detailberita/66 777/ptsl-bukan-bagibagi-tanah-sumbar-dijatah-65000sertifikat\&ei=KOf5X1Fl\&lc=id- di akses tanggal 8 november 2017 pukul 09.30 WIB

11 persadanews.com/atr-bpn-kota-padangdapatkan-20-000-kuota-ptsl-dari kementerian-agrariadan-tata-ruang-badan-pertanahan-nasional/ di akses tanggal 8 november 2017 pukul $09.40 \mathrm{WIB}$ perkebunan ini berdampingan dengan kawasan hutan lindung. Tanah ulayat kaum dalam masyarakat minangkabau khususnya di Kecamatan Bungus Teluk Kabung kota Padang dalam kehidupan sehari-hari disebut dengan tanah pusaka tinggi (tanah pusako tinggi) yaitu tanah milik adat yang dimiliki secara bersama. Tanah ulayat kaum ini didaftarkan oleh anggota kaum melalui program Pendaftaran tanah sistematis lengkap tanpa diketahui oleh mamak kepala waris yang nantinya menjadi permasalahan atau sengketa, baik yang berasal dari anggota kaum itu sendiri maupun diluar anggota kaum.

Berdasarkan uraian-uraian diatas menarik untuk diadakan penelitian dan membahas pendaftaran tanah khususnya pendaftaran tanah ulayat kaum yang dilaksanakan melalui program Pendaftaran Tanah Sistematis Lengkap. Untuk itu dicoba mengangkatnya dalam artikel ini.

\section{METODE PENELITIAN}

Metode yang digunakan dalam artikel ini adalah metode penelitian yuridis empiris. Pengertian yuridis disini dimaksudkan bahwa dalam meninjau dan menganalisis hasil penelitian digunakan prinsip-prinsip dan asasasas hukum. Sedangkan pengertian empiris adalah penelitian terhadap kaidah-kaidah hukum yang ada dimasyarakat. ${ }^{12}$ Oleh karena itu data yang diperlukan adalah data primer dan data sekunder dalam Peraturan Perundang-Undangan dan kenyataan di lapangan.

Metode pendekatan yuridis empiris yaitu penelitian hukum dengan cara pendekatan fakta yang ada dengan jalan mengadakan pengamatan dan penelitian dilapangan kemudian dikaji dan ditelaah berdasarkan peraturan perundang-undangan 
yang terkait sebagai acuan untuk memecahkan masalah. $^{13}$

Rumusan Masalah dalam tulisan ini adalah bagaimana Pelaksanaan Pendaftaran Tanah Ulayat Kaum Melalui Program Pendaftaran Tanah Sistematis Lengkap di Kecamatan Bungus Teluk Kabung, dan apa saja kendala apa yang dihadapi dalam Pelaksanaan Pendaftaran Tanah Ulayat Kaum Melalui Program Pendaftaran Tanah Sistematis Lengkap di Kecamatan Bungus Teluk Kabung

Penelitian yang dilakukan adalah bersifat deskriptif analitis yang bisa memberikan gambaran yang luas tentang pemecahan masalah dengan cara memaparkan objek yang diteliti sebagaimana adanya berdasarkan fakta-fakta aktual pada saat sekarang, tidak terbatas hanya sampai pada pengumpulan data, tetapi meliputi analisis dan interprestasi tentang arti data-data tersebut. Norma-norma hukum tanah nasional digambarkan dalam kaitan terhadap teori hukum dan praktek Pelaksanaan Pendaftaran Tanah Ulayat Kaum Secara Pendaftaran Tanah Sistematis Lengkap (PTSL) di Kecamatan Bungus Teluk Kabung.

Berkaitan dengan hal tersebut diatas, kerangka teori yang digunakan dalam penulisan ini adalah Teori Kepastian dan Teori Keadilan. Jenis dan sumber data dalam penulisan ini adalah data priimer dan data sekunder yang terdiri dari bahan hukum primer, bahan hukum sekunder, dan bahan hukum tersier dengan didukung teknik pengumpulan data berupa studi dokumentasi dan wawancara (interview).

\section{PELAKSANAAN PENDAFTARAN \\ TANAH ULAYAT KAUM MELALUI PROGRAM PENDAFTARAN TANAH SISTEMATIS LENGKAP DI KECAMATAN BUNGUS TELUK KABUNG}

13 Ronny Hanitjo Soemitro, Metode Penelitian Hukum dan Jurumetri, (Jakarta: Ghalmis Indonesia ). 52
Pensertifikatan tanah melalui program pendaftaran tanah sistematis lengkap berdasarkan dasar hukum Peraturan Menteri Agraria dan Tata Ruang/Kepala Badan Pertanahan Nasional Republik Indonesia Nomor 12 Tahun 2017 tentang Percepatan Pelaksanaan Pendaftaran Tanah Sistematis lengkap. Berdasarkan wawancara Penulis dengan Ibu Silvia Septriana S.H selaku Kepala Sub Seksi Pemeliharaan Data Hak tanah dan Pembinaan PPAT menerangkan Prosedur Pensertifikatan tanah secara sistematis dan lengkap di Badan Pertanahan Kota Padang harus melalui beberapa tahap. ${ }^{14}$

1. Persiapan

a. Sosialisasi. Seluruh jajaran kementrian Agraria dan Tata Ruang/Badan Pertanahan Nasional memberikan informasi akan dilaksanakannya Pendataran Tanah Sistematis Lengkap kepada masyarakat secara langsung maupun melalui media.

b. Penetapan lokasi dan jumlah bidang. Lokasi ditetapkan dengan meperhatikan ketersediaan peta kerja, ketersediaan dan kemampuan optimal, dan satgas. Apabila volume bidang pada desa/kelurahan yang ditetapkan lebih kecil dari kapasitas jumlah tanah yang dapat dikerjakan oleh panitia, maka panitia tersebut dapat mengerjakan pada beberapa kelurahan. Satgas yang membantu panitia dapat dibentuk pada masing-masing kelurahan. Lokasi yang telah disiapkan ditetapkan oleh Kepala Kantor Pertanahan Kota Padang. Jika lokasi yang ditetapkan terdiri dari beberapa kelurahan, upayakan agar kelurahan yang menjadi obyek Pendaftaran Tanah Sistematis Lengkap letaknya berdekatan. Dalam hal di pandang perlu, tidak efesiensi dan efektifitas capaian target kinerja

14 Silvia Septriana (Kepala Sub Seksi Pemeliharaan Data Hak Tanah dan Pembinaan PPAT), Wawancara, tanggal 25 Juni 2018 
Pendaftaran Tanah Sistematis Lengkap maka dimungkinkan penyebaran target Pendaftaran Tanah Sistematis Lengkap dikonsentrasikan di kota Padang. Jika letak kelurahan satu dengan kelurahan yang lainnya memerlukan waktu perjalanan yang panjang, sementara jumlah bidang dalam satu kelurahan tidak memerlukan satgas yuridis maka cukup dibentuk satu panitia dengan 1 pengumpul data yuridis. Jika diperlukan Kepala Kantor dapat melakukan perubahan lokasi yang sudah ditetapkan dan melaporkan ke Kantor Wilayah BPN Provinsi. Lokasi tanah obyek landreform yang ditetapkan menjadi obyek pendaftaran tanah sistematis lengkap dengan sendirinya dikeluarkan dari obyek landreform.

c. Perencanaan tenaga panitia dan Satgas Yuridis. Kepala Kantor Wilayah Badan Pertanahan Nasional Provinsi melakukan inventarisasi jumlah pegawai yang dapat ditugaskan sebagai panitia dan satgas. Satu panitia dalam Pendaftaran Tanah Sistematis Lengkap disebut Panitia Ajudikasi Percepatan berjumalah 4 orang pegawai Badan Pertanahan Nasional ditambah satu kelurahan, dan anggotanya dapat ditambah sesuai kebutuhan. Untuk pengumpulan data, Panitia Ajudikasi Percepatan dibantu oleh Satgas yang terdiri atas paling sedikit 1 (satu) orang Pegawai Negeri Sipil Badan Pertanahan Nasional dan 1 (satu) orang warga setempat sesuai kebutuhan. Satu Panitia Ajudikasi Percepatan dapat didampingi/dibantu oleh pengumpul data atau satgas sesuai dengan volume/target. Satu orang pengumpul data yuridis mempunyai target sebanyak minimal 15 berkas/bidang dalam satu hari kerja. Pengumpulan dan analisis data yuridis diselesaikan dalam satu tahun anggaran dengan memperhatikan jangka waktu tahapan kegiatan. Perbandingan antara kapasitas Panitia Ajudikasi Percepatan dan Satgas Yuridis dengan target volume bidang yang ditentukan berpedoman pada Lampiran 5 Perbandingan Antara Kapasitas Panitia Dan Satgas Yuridis Dengan Target Volume Bidang

2. Pembentukan Panitia Ajudikasi Percepatan. Penyiapan pembentukan Panitia Ajudikasi Percepatan dilaksanakan di Kantor Wilayah Badan Pertanahan Nasional. Dalam hal diperlukan, Kepala Kantor Wilayah Badan Pertanahan Nasional dapat menugaskan pegawai dari Kantor Pertanahan membantu pelaksanaan Pendaftaran Tanah Sistematis Lengkap di Kantor Pertanahan Kabupaten/Kota lain dalam satu wilayah Provinsi. Panitia Ajudikasi Percepatan dan Satgas ditetapkan dengan Keputusan Kepala Kantor Pertanahan Kabupaten/Kota sebagaimana Lampiran II Peraturan Menteri Agraria dan Tata Ruang/Kepala Badan Pertanahan Nasional Nomor 35 Tahun 2016. Dalam hal diperlukan, anggota panitia dapat ditunjuk pegawai dari komponen seksi lain selain dari seksi Hubungan Hukum Keagrarian dan Infrastruktur Keagrariaan di lingkungan Kantor Wilayah Badan Pertanahan Nasional Provinsi maupun Kantor Pertanahan Kabupaten/Kota. Untuk memperlancar pendaftaran tanah sistematis lengkap, Kepala Kantor Pertanahan dapat menetapkan unsur Kelurahan/Desa, RT/RW atau warga setempat melaksankan pengumpulan data.

3. Pelatihan Untuk mempersiapkan kelancaran pelaksanaan tugas Pendaftaran Tanah Sistematis Lengkap, perlu dilakukan pelatihan teknis "Pendaftaran Tanah Sistematis", bagi Panitia Ajudikasi Percepatan dan Satgas yang meliputi materi pengumpulan data, pengolahan data dan 
tata laksana kegiatan Pendaftaran Tanah Sistematis Lengkap, yang dilaksanakan oleh Kantor Wilayah Badan Pertanahan Nasional Provinsi.

4. Penyuluhan. Penyuluhan dilakukan selambat-lambatnya pada Bulan Kedua. Penyuluhan dilakukan oleh Kantor Pertanahan beserta Panitia Ajudikasi Percepatan dan Satgas Yuridis bersama Satgas Fisik. Dalam penyuluhan disampaikan tahapan kegiatan Pendaftaran Tanah Sistematis Lengkap, dokumen yuridis yang perlu disiapkan, jadwal pengumpulan data yuridis, kluster hasil akhir kegiatan ajudikasi percepatan. Mengajak partisipasi masyarakat dalam pelaksanaan Pendaftaran Tanah Sistematis Lengkap dengan memperhatikan hak dan kewajibannya. Penjelasan tentang pembiayaan yang disediakan oleh Pemerintah melalui kegiatan Pendaftaran Tanah Sistematis Lengkap dan kemungkinan biaya/bea/pajak yang akan ditanggung oleh peserta.

5. Pengumpulan Data Yuridis. Pengumpulan data yuridis dilakukan selambat-lambatnya pada Bulan Ketiga. Pengumpulan/inventarisasi data dilakukan oleh Satgas. Pelaksanaan pengumpulan data yuridis dilaksanakan bersamaan waktunya dengan pemetaan partisipatif yang dilakukan oleh Satgas Fisik. Inventarisasi/pengumpulan data yuridis dilakukan dengan formulir-formulir isian inventarisasi dan identifikasi peserta Pendaftaran Tanah Sistematis Lengkap. Mendokumentasikan hasil inventarisasi/pengumpulan data.

6. Pengolahan Data Yuridis dan Pembuktian Hak. Data yuridis yang diinventarisisasi/terkumpul dilakukan analisis oleh Panitia Ajudikasi Percepatan, menyangkut data kepemilikan yang menunjukkan hubungan hukum antara peserta Pendaftaran Tanah Sistematis
Lengkap dengan tanah obyek Pendaftaran Tanah Sistematis Lengkap.

7. Pemeriksaan Tanah. Pemeriksaan tanah dilakukan untuk memastikan keterangan yang tertuang di dalam data yuridis sesuai dengan keadaan di lapangan. Dilakukan dengan cara menggali informasi yang meliputi kesesuaian nama dan profesi peserta Pendaftaran Tanah Sistematis Lengkap. Membandingkan keterangan yang tertera di dalam formulir isian inventarisasi dan dokumen/data yuridis dengan kesesuaian dengan kondisi penguasaan, penggunaan tanah tersebut di lapangan, serta kesesuaian letak, batas dan luas yang tertuang dalam data fisik (Peta Bidang Tanah) dengan kenyataan di lapangan. Hasil pemeriksaan tanah mendukung analisis terhadap data yuridis yang menghasilkan K1, K2, K3, dan K4. Hasil pemeriksaan tanah dibuatkan dalam berita Acara/risalah pemeriksaan tanah sesuai peraturan Kepala Badan Pertanahan Nasional Republik Indonesia Nomor 7 Tahun 2007.

8. Pengumuman. Hasil pemeriksaan tanah yang menyimpulkan dapat dibukukan dan atau diterbitkannya Sertipikat hak atas tanah atas satu bidang tanah diumumkan dalam papan pengumuman di Kantor Pertanahan dan/atau Kantor Kelurahan/Desa dan/atau Sekretariat RT/RW lokasi bidang tanah tersebut selama 14 hari, dengan tujuan untuk diketahui khalayak masyarakat dan memberi kesempatan kepada pihakpihak yang berkepentingan untuk menyampaikan keberatan jika ada keberatan.

9. Pengesahan. Hasil dari pengumuman disahkan dalam Berita Acara Hasil Pengumuman oleh Panitia Ajudikasi Percepatan Lampiran 7 Berita Acara Pengesahan Hasil Pengumuman.

10. Penerbitan SK Penetapan Hak dan SK Penegasan/Pengakuan Hak. Berdasarkan Berita Acara Hasil Pengumuman Panitia 
Ajudikasi Bidang Yuridis Menyiapkan Naskah SK Penetapan Hak atau SK Penegasan/Pangakuan Hak. Ketua Panitia Ajudikasi Percepatan menandatangani Surat Keputusan Penetapan Hak atau Surat Keputusan Penegasan/Pengakuan Hak. Dalam rangka penerbitan Surat Keputusan Pemberian Hak, bagi para pihak yang mampu membayar BPHTB, bukti pembayaran dibawa pada saat pendaftaran hak. Apabila peserta Pendaftaran Tanah Sistematis Lengkap tidak mampu/belum dapat memenuhi BPHTB, maka yang bersangkutan harus membuat surat penyataan sebagaimana lampiran $\mathrm{V}$ Peraturan Menteri Agraria Dan Tata Ruang/Kepala Badan Pertanahan Nasional Nomor 35 Tahun 2016 Tentang Percepatan Pelaksanaan Pendaftaran Tanah Sistematis Lengkap.

11. Pembukuan Hak. Panitia Ajudikasi Bidang Yuridis menyiapkan/mencetak Buku Tanah dan Ketua Panitia Ajudikasi Percepatan menandatangani Buku Tanah.

12. Penerbitan dan penyerahan Sertipikat. Panitia Ajudikasi Bidang Yuridis menyiapkan/mencetak Sertipikat Hak Atas Tanah.Kepala Kantor Pertanahan menandatangani Sertipikat hak atas tanah atau dapat mendelegasikan kewenangan penandatanganan Sertipikat kepada Ketua Panitia Ajudikasi Percepatan. Panitia Ajudikasi Percepatan Menyerahkan Sertipikat Hak Atas Tanah kepada Pemegang Hak atau kuasanya dengan mencatatnya dalam daftar isian penyerahan Sertipikat.

13. Pengelolaan Warkah/Dokumen. Panitia Ajudikasi Percepatan mendokumentasikan seluruh warkah/dokumen data fisik maupun yuridis. Panitia Ajudikasi Percepatan menyerahkan seluruh dokumen data fisik maupun yuridis yang telah digunakan dalam proses ajudikasi percepatan dan telah terdokumentasi dengan baik disertai berita acara serah terima kepada Kantor Pertanahan setempat (Lampiran 12 : Berita Acara Serah Terima Hasil Kegiatan Dari Panitia Ajudikasi Percepatan Kepada Kantor Pertanahan), pada akhir masa kerjanya dan sebelum meninggalkan lokasi Pendaftaran Tanah Sistematis Lengkap. Warkah/dokumen yuridis yang diserahterimakan terdiri atas; Dokumen data yuridis (yang dikumpulkan dari pemohon, berit acara yang dibuat panitia, pengumuman dan Surat Keputusan); Buku Tanah; Surat Ukur; Bukti-bukti administrasi keuangan.

14. Pelaporan. Laporan pelaksanaan Panitia Ajudikasi Percepatan dilakukan secara berjenjang dan berkala dari Kantor Pertanahan kepada Kepala Kantor Wilayah selanjutnya kepada Kementerian Agraria dan Tata Ruang/Badan Pertanahan Nasional, dengan menggunakan SKMPP. Laporan kemajuan pekerjaan fisik pelaksanaan pendaftaran tanah sistematis bidang yuridis selain dilaksanakan melalui SKMPP, dilakukan pula secara berkala kepada Menteri Agraria dan Tata Ruang/Kepala Badan Pertanahan Nasional c.q. Direktur Jenderal Hubungan Hukum Keagrariaan berkenaan dengan permasalahan yang dijumpai dalam setiap tahapan kegiatan pekerjaan. Penanggung jawab pelaksanaan laporan untuk Kantor Pertanahan adalah Kepala Seksi Hubungan Hukum Keagrariaan dan di tingkat Kantor Wilayah Badan Pertanahan Nasional adalah Kepala Bidang Hubungan Hukum Keagrariaan. Laporan yang telah disiapkan pada Kantor Pertanahan Kabupaten/Kota ditandatangani oleh Kepala Kantor Pertanahan Kabupaten/Kota setempat, dan yang telah disiapkan pada Kantor Wilayah Badan Pertanahan Nasional ditandatangani oleh Kepala Kantor Wilayah Badan Pertanahan Nasional Provinsi yang bersangkutan. Laporan dari Kepala Kantor 
Pertanahan Kabupaten/Kota kepada Kepala Kantor Wilayah Badan Pertanahan Nasional Provinsi dan darKepala Kantor Wilayah Badan Pertanahan Nasional Provinsi harus sinkron dan merupakan laporan pelaksanaan kegiatan secara utuh.

Kegiatan PTSL (Pendaftaran Tanah Sistematis Lengkap) sangat menuntut adanya jaminan kepastian hukum. Salah satu persoalan penting terkait dengan kepastian hukum tersebut adalah asas publisitas yang mempuyai perbedaan pengaturan antara peraturan pemerintah dengan peraturan menteri. Untuk memenuhi asas publisitas dalam pembuktian pemilikan tanah maka dilaksanakan pengumuman data fsik dan data yuridis selama 14 (empat belas) hari kalender (Pasal 21 Peraturan ATR/Ka. BPN No. 12 Tahun 2017).

Ketentuan ini berbeda dengan Pasal 26 PP No. 24 Tahun 1997 tentang Pendaftaran Tanah yang mensyaratkan 30 hari dan Pasal 63 PMNA/Ka. BPN No. 3 Tahun 1997 tentang Ketentuan Pelaksanaan Peraturan Pemerintah No. 24 Tahun 1997 tentang Pendaftaran Tanah. Pengaturan asas publisitas yang berbeda memberikan ruang potensi sengketa di kemudian hari, karena pada asasnya peraturan yang lebih rendah tidak boleh bertentangan dengan peraturan yang lebih tinggi.

Menurut Soeprapto berdasarkan teori jenjang norma hukum dikemukakan oleh Hans Kelsen yaitu stufentheorie, yang menyebutkan bahwa norma-norma hukum itu berjenjangjenjang dan berlapis-lapis dalam suatu hierarki, dimana suatu norma yang lebih rendah berlaku, bersumber dan berdasar pada norma yang lebih tinggi, norma yang lebih tinggi berlaku, bersumber dan berdasar pada norma yang lebih tinggi lagi, demikian seterusnya sampai pada suatu norma yang disebut norma dasar (grundnorm). ${ }^{15}$

Senada dengan Sitorus menyatakan, ketidaksinkronan itu membatalkan aturan hukum yang lebih rendah, namun dalam praktik penyelenggaraan bernegara ketidaksinkronan aturan itu tidak otomatis membatalkan aturan yang lebih rendah sebelum aturan yang lebih rendah dibatalkan oleh pengadilan yang berwenang dalam melakukan judicial review. Oleh karena itulah, Permen tentang PTSL tetap berlaku sebelum ada putusan judicial review dari Mahkamah Agung.

Pertentangan pengaturan antara Peraturan Menteri ATR/Ka. BPN No.12 Tahun 2017 dengan PP No. 24 Tahun 1997 mengenai waktu pengumuman data fsik dan data yuridis. Ketentuan ini apabila ditinjau dari asas-asas peraturan perundang-undangan dapat diuraikan sebagai berikut;

Pertama, Asas lex superior derogat legi inferior yang artinya peraturan yang lebih tinggi mengesampingkan yang rendah (asas hierarki), maka yang digunakan adalah PP 24 Tahun 1997 karena PP lebih tinggi derajatnya daripada Peraturan Menteri, karena ketentuan Peraturan Menteri derajatnya lebih rendah tidak dapat mengubah atau mengesampingkan ketentuan PP yang lebih tinggi derajatnya, bahkan peraturan menteri tidak mempunyai kekuatan hukum dan tidak mengikat apabila isinya bertentangan dengan PP;

Kedua, asas Lex Specialis Derogat Legi Generali yaitu asas hukum yang bersifat khusus mengesampingkan hukum yang bersifat umum, juga tidak dapat diterapkan dalam pengunaan asas ini karena ketentuan lex specialis harus sederajat dengan ketentuanketentuan lex generalis, misalnya UU dengan UU, PP dengan PP, dan seterusnya;

15 MFI Soeprapto, Ilmu Perundang-Undangan: Jenis, Fungsi, Dan Materi Muatan, (Yogyakarta: Kanisius, 2010). 45 . 
Ketiga, Asas Lex Posterior Derogat Legi Priori, Asas ini juga untuk peraturan yang sederajat, peraturan yang paling baru melumpuhkan peraturan yang lama.

Persoalan selanjutnya, bagaimanakah kekuatan mengikat Peraturan Menteri ATR/Ka. BPN No.12 Tahun 2017. Merujuk Pasal 8 ayat (2) UU No. 12/2011 tentang Pembentukan Peraturan Perundang-undangan menegaskan: "Peraturan Perundang-undangan sebagaimana dimaksud pada ayat (1) diakui keberadaannya dan mempunyai kekuatan hukum mengikat sepanjang diperintahkan oleh Peraturan Perundang-undangan yang lebih tinggi atau dibentuk berdasarkan kewenangan".

Dalam ketentuan ini terdapat dua syarat agar peraturan menteri memiliki kekuatan mengikat sebagai peraturan perundang-undangan, yaitu diperintahkan oleh peraturan perundang-undangan yang lebih tinggi atau dibentuk berdasarkan kewenangan. Apabila merujuk pada Pasal 19 UUPA, maka kegiatan PTSL merupakan perintah dari Pasal 19 UUPA sebagai sumber hukum peraturan menteri. Artinya peraturan yang lebih rendah tidak boleh bertentangan peraturan yang lebih tinggi.

Untuk mengatasi pertentangan ini setidak-tidaknya dilakukan: Pertama, sinkronisasi/harmonisasi antara PP dengan meraturan menteri supaya memenuhi syarat formal kepastian hukum dan perlindungan hukum terhadap pemegang hak atas tanah. Kedua, Pengaturan mengenai PTSL semestinya diatur dalam peraturan pemerintah sehingga mempuyai derajat yang lebih tinggi dibandingkan dengan peraturan menteri dan/atau merivisi secara parsial untuk mendukung percepatan PTSL atau menganti dengan PP yang baru sesuai dengan kondisi zaman saat ini..

$$
\text { Adapun proses permohonan }
$$
pendaftaran tanah ulayat kaum melalui program Pendaftaran Tanah Sistematis
Lengkap di Kecamatan Bungus Teluk Kabung adalah sebagai berikut $:^{16}$

1. Pemohon mengajukan permohonan pendaftaran tanah hak milik kaum atau hak milik perorangan anggota kaum ke petugas satgas yuridis dengan mengisi berupa Surat Pernyataan Penguasaan Fisik Bidang Tanah. Surat Pernyataan Penguasaan Fisik Bidang Tanah ini ditanda tangani oleh pemohon dan disaksikan oleh dua orang. Adapun Surat pernyataan penguasaaan fisik bidang tanah (milik kaum) tersebut memuat antara lain :

a. Identitas pemohon (nama, NIK, agama, umur, pekerjaan, Alamat)

b. Lokasi tanah

c. Luas tanah

d. Penggunaan tanah

e. Batas-batas tanah (utara, timur, selatan, barat)

f. Dasar pemilikan tanah secara turun temurun

g. Keterangan keadaan tanah tidak dijadikan/menjadi jaminan sesuatu hutang dan tidak didalam sengketa.

h. Identitas para saksi (2 orang saksi)

i. Pernyataan yang menyatakan bahwa apabila ternyata pernyataan tersebut tidak benar, maka bersedia dituntut dihadapan yang berwenang baik perdata maupun pidana dan segala akibat yang timbul menjadi tanggung jawab pemohon dan bersedia dituntut sesuai dengan ketentuan hukum yang berlaku serta tidak melibatkan pihak lain dan bersedia atas sertipikat hak atas tanah yang telah terbit dibatalkan oleh pejabat yang berwenang.

2. Tanda tangan pemohon dan 2 orang saksi.

3. Permohonan tersebut dilampirkan dengan bukti kepemilikan tanah. Pembuktian tersebut dibuktikan dengan alat-alat bukti mengenai adanya hak tersebut berupa bukti 
tetulis, keterangan saksi dan atau pernyataan yang bersangkutan yang kadar kebenaranya dianggap cukup untuk mendaftarkan haknya, pemegang haknya dan hak-hak lain-lain yang membebaninya Apabila bukti kepemilikan tidak lengkap atau tidak ada, maka pembuktian itu dapat dilakukan dengan bukti lain, yang dilengkapi dengan Pernyataan Penguasaan Fisik dari yang bersangkutan dan keterangan yang dapat dipercaya dari sekurang-kurangnya 2 orang saksi dari lingkungan masyarakat setempat dan tidak mempunyai hubungan keluarga dengan yang bersangkutan. Setelah semua syaratsyarat diatas dipenuhi, pemohon kemudian memberikanya ke petugas satgas yuridis Kantor Pertanahan Nasional Kota Padang untuk dapat diukur, tapi sebelum pengukuran dilakukan harus dipenuhi syarat-syarat dalam pengukuran adalah menetapkan batas-batas tanah dan memasang tanda-tanda batas tanah.

4. BPN Kota Padang akan menurunkan petugas kelapangan untuk mengadakan pengukuran dan pemetaan. Setelah itu dibuatkan surat ukur untuk keperluan pendaftaranya. Surat ukur adalah dokumen yang memuat data fisik suatu bidang tanah dalam bentuk peta dan uraian.

5. Selanjutnya diadakan penelitian penguasaan tanah dilapangan oleh Panitia Adjudikasi yang terdiri dari kepala seksi pada Kantor Pertanahan beserta Lurah dan dituangkan dalam suatu daftar isian. Daftar isian ini beserta peta bidang tanah sebagai hasil pengukuran, yang setelah ditanda tangani oleh Panitia A, akan diumumkan selama empat belas berturut-turut (14 hari) di Kantor BPN Kota Padang, Kantor Kecamatan dan Kantor Kelurahan setempat dan media massa untuk memeberi kesempatan kepada pihak yang berkepentingan mengajukan keberatan
6. Apabila selama pengumuman tidak ada gugatan dari pihak lain maka oleh BPN Kota Padang membuat berita acara pengesahan pengumuman, setelah itu barulah diterbitkan sertifikat atas nama pemohon yaitu anggota kaum atau mamak kepala waris.

Kota Padang mendapat target pensertipikatan tanah secara PTSL sebanyak 20.100 yang masing-masing terbagi dalam dua lokasi yaitu Kecamatan Bungus teluk kabung sebanyak 10.100 bidang sertipikat dan Lubuk Begalung sebanyak 10.000 bidang sertipikat. Sedangkan penyelesaian proses pendaftaran tanah terdiri dari 4 (empat) kategori (Pasal 25 ayat 2 Peraturan Mentri Agraria dan Tata Ruang/Kepala Badan Pertanahan Nasional Republik Indonesia No 12 tahun 2017 Tentang Pendaftaran Tanah Sistematis Lengkap) yaitu :

1. Kategori 1 yaitu bidang tanah data fisik dan data yuridisnya memenuhi syarat untuk diterbitkan sertipikat hak atas tanah

2. Kategori 2 yaitu bidang tanah yang data fisik dan data yuridisnya memenuhi syarat untuk diterbitkan sertipikat hak atas tanahnya namun terdapat perkara dipengadilan

3. Kategori 3 yaitu bidang tanah yang data fisik dan data yuridisnya tidak dapat dibukukan dan diterbitkan sertipikat hak atas tanah karena subyek haknya wajib terlebih dahulu memenuhi persyaratan terentu yang ditetapkan dalam peraturan mentri ini.

4. Kategori 4 yaitu bidang tanah yang obyek dan subyeknya sudah terdaftar dan sudah bersertipikat hak atas tanah, sehingga tidak menjadi obyek PTSL secara langsung namun wajib dilakukan pengintegrasian peta-peta bidang tanahnya kedalam peta pendaftaran tanah sistematis lengkap.

Bidang tanah yang dapat diterbitkan sertipikat hak atas tanah (Kategori 1) diberikan kepada (Pasal 26 ayat 1 Peraturan Mentri 
Agraria dan Tata Ruang/Kepala Badan Pertanahan Nasional Republik Indonesia No 12 tahun 2017 Tentang Pendaftaran Tanah Sistematis Lengkap):

1. Perorangan Warga Negara Indonesia

2. Masyarakat yang termasuk dalam program pemerintah bidang perumahan sederhana

3. Badan hukum keagamaan dan badan hukum sosial yang sesuai antara peruntukan dan penggunaan tanahnya.

4. Pegawai Negeri Sipil (PNS), Pensiunan PNS, Tentara Nasional Indonesia (TNI), Kepolisian Republik Indonesia (POLRI), dan para Purnawirawan TNI dan POLRI.

5. Instansi Pemerintah Daerah dan Pemerintah Daerah, untuk melaksanakan tugas dan fungsinya dan tidak bersifat profit.

6. Nadzir, atau

7. Masyarakat Hukum Adat

Persayaratan yang harus dipenuhi dalam Kategori 1 ini adalah sebagai berikut (Pasal 26 ayat 2 Peraturan Mentri Agraria dan Tata Ruang/Kepala Badan Pertanahan Nasional Republik Indonesia No 12 tahun 2017 Tentang Pendaftaran Tanah Sistematis Lengkap):

1. Identitas subyek PTSL berupa; Kartu Tanda Penduduk atau keterangan identitas lainya bagi perorangan Warga Negara Indonesia; Akta Pendirian dan Pengesahan Badan Hukum bagi Badan Hukum sosial keagamaan; Peraturan perundangan tentang pembentukan Instansi Pemerintah/Pemerintah Daerah bagi Instansi Pemerintah dan Pemerintah Daerah atau; Kartu Tanda Penduduk atau keterangan identitas lainya dilengkapi Akta Ikrar Wakaf atau akta pengganti akta Ikrar Wakaf bagi Nadzir.

2. Tanah dikuasai dan dimanfaatkan sendiri oleh pemiliknya, baik langsung maupun tidak langsung.

Dari uraian diatas dapat disimpulkan bahwa syarat untuk yang harus dipenuhi untuk
Pendaftaran tanah ulayat kaum melalui program PTSL adalah cukup dengan memasukan permohonan dan dilengkapi dengan surat penguasaan fisik bidang yang ditanda tangani oleh pemohon dan 2 orang saksi tanpa melibatkan pihak kelurahan, ninik mamak serta Kerapatan Adat Nagari setempat.

Kecamatan Bungus Teluk Kabung berada dalam jarak $12 \mathrm{KM}$ dari pusat kota dan berbatasan langsung dengan Kabupatena Pesisir Selatan dengan Luas 100,78 KM르, yang tediri dari 6 Kelurahan diantaranya :

1. Kelurahan Bungus Barat

2. Kelurahan Bungus Selatan

3. Kelurahan Bungus Timur

4. Kelurahan Teluk Kabung Selatan

5. Kelurahan Teluk Kabung Tengah

6. Kelurahan Teluk Kabung Utara.

Berdasarkan wawancara penulis dengan Bapak Hengki Setiawan sebagai Kepala Sub Seksi Pengukuran dan Pemetaan dasar dan Tematik menyatakan bahwa Realisasi pensertifikatan tanah melalui program pendaftaran tanah sistematis lengkap di Kecamatan Bungus Teluk Kabung yang penulis tuangkan dalam bentuk tabel di bawah ini $:^{17}$

\begin{tabular}{|l|l|l|l|l|}
\hline \multirow{2}{*}{ KELURAHAN } & \multicolumn{4}{|c|}{ JUMLAH } \\
\cline { 2 - 5 } & K1 & K2 & K3 & K4 \\
\hline Bungus Barat & 185 & 0 & 3.588 & 0 \\
\hline $\begin{array}{l}\text { Bungus } \\
\text { Selatan }\end{array}$ & 44 & 0 & 367 & 0 \\
\hline Bungus Timur & 509 & 0 & 8221 & 4 \\
\hline $\begin{array}{l}\text { Teluk Kabung } \\
\text { Selatan }\end{array}$ & 126 & 0 & 227 & 0 \\
\hline $\begin{array}{l}\text { Teluk Kabung } \\
\text { Tengah }\end{array}$ & 109 & 0 & 16 & 0 \\
\hline $\begin{array}{l}\text { Teluk Kabung } \\
\text { Utara }\end{array}$ & 79 & 0 & 440 & 0 \\
\hline Total & 1.052 & 0 & 12.859 & 4 \\
\hline$\%$ & 9,6 & & & \\
\hline
\end{tabular}

Sumber: Kantor Pertanahan Kota Padang, 2017

17 Hengki (Kepala Sub Seksi Pengukuran, Pemetaan Dasar dan Tematik), Wawancara, tanggal 25 Juni 18. 
Dari tabel diatas penulis dapat menyimpulkan bahwa realisasi pensertpikatan tanah ulayat kaum melalaui program pendaftaran tanah sistematis lengkap di Kecamatan Bungus Teluk Kabung sebanyak 10.100 bidang belum mencapai target karna hanya 9,6\% yang bisa diterbitkan sertipikatnya (Kategori 1) dan yang paling banyak masuk dalam kategori 3 yaitu Bidang tanah yang data fisik dan data yuridisnya tidak dapat dibukukan dan diterbitkan sertipikat yaitu sebanyak 12.859 bidang. Bidang tanah yang data fisik dan data yuridisnya tidak dapat dibukukan dan diterbitkan sertipikat (Kategori 3) dipengaruhi oleh beberapa kendala-kedala.

\section{KENDALA-KEDALA DALAM PELAKSANAAN PENDAFTARAN TANAH MELALUI PROGRAM PENDAFTARAN TANAH SISTEMATIS LENGKAP DI KECAMATAN BUNGUS TELUK KABUNG}

Pelaksanaan pendaftaran tanah sistematis lengkap diharapkan selancar dan sebaik sesuai dengan jiwa dan kehendak Peraturan Perundang-Undangan, dimana di lapangan ditemui beberapa kendala di antaranya;

\section{Dalam hal penentuan subyek pendaftaran tanah.}

Subyek hukum adalah segala pendukung hak dan kewajiban. Subyek hukum ini dapat berupa orang/person dan badan hukum. Dalam hal pendaftaran tanah di Indonesia, UUPA menentukan bahwa yang dapat menjadi subyek hak adalah Warga Negara Indonesia dan badan hukum. Undangundang menentukan hanya warga negara Indonesia yang dapat mempunyai hubungan yang sepenuhnya dengan bumi, air dan ruang angkasa tanpa membedakan antara laki-laki dan perempuan. Artinya UUPA mengandung prinsip bahwa orang asing tidak diperbolehkan mempunyai hak atas tanah terutama hak milik.

Subyek hukum yang dapat mempunyai hak milik atau suatu hak atas tanah di
Indonesia dinyatakan dalam Pasal 21 UUPA bahwa :

(1) Hanya warga-negara Indonesia dapat mempunyai hak milik.

(2) Oleh Pemerintah ditetapkan badanbadan hukum yang dapat mempunyai hak milik dan syaratsyaratnya.

(3) Orang asing yang sesudah berlakunya Undang-undang ini memperoleh hak milik karena pewarisan tanpa wasiat atau percampuran harta karena perkawinan, demikian pula warganegara Indonesia yang mempunyai hak milik dan setelah berlakunya Undangundang ini kehilangan kewarganegaraannya wajib melepaskan hak itu di dalam jangka waktu satu tahun sejak diperolehnya hak tersebut atau hilangnya kewarganegaraan itu. Jika sesudah jangka waktu tersebut lampau hak milik itu dilepaskan, maka hak tersebut hapus karena hukum dan tanahnya jatuh pada Negara, dengan ketentuan bahwa hak-hak pihak lain yang membebaninya tetap berlangsung.

(4) Selama seseorang di samping kewarganegaraan Indonesianya mempunyai kewarganegaraan asing maka ia tidak dapat mempunyai tanah dengan hak milik dan baginya berlaku ketentuan dalam ayat (3) pasal ini.

Dalam pelaksanaan pendaftaran tanah ulayat kaum sulit menentukan siapa yang akan menjadi subyek atau pemegang haknya, karena kepemilkan tanah ulayat kaum adalah secara komunal (bersama) oleh semua anggota kaum yang berangkutan. Subyek hak dalam pendaftaran tanah akan berpengaruh dan sangat menentukan dalam pemilikan tanah yang didaftarkan tersebut. Sehingga tidak jarang terjadi sengketa antara anggota kaum dalam menentukan siapa yang akan dicantumkan namanya dalam sertipikat 
nantinya. Dalam hukum positif pemilik terhadap tanah yang didaftarkan atau disertipikatkan adalah orang yang namanya tercantum dalam sertifikat.

Apabila terjadi suatu peristiwa hukum seperti pewarisan, maka yang berhak mewarisi adalah anak dan istri/suami. Sedangkan dalam ketentuan hukum adat Minangkabau tanah dimiliki secara bersama dan turun temurun oleh semua anggota kaum menurut sistem kekerabatan matrilineal dan pewarisannya tidak kepada anak, istri atau suami tetapi kepada kamanakan (keponakan) atau anak dari saudara perempuan.

Harta pusaka tinggi atau tanah ulayat kaum yang telah diberikan kepada anggota kaum sebagai hak "ganggam bauntuak" hanya merupakan hak pakai bagi anggota kaum yang bersangkutan, apabila tanah tersebut tidak dipakai dan dimanfaatkan lagi maka akan kembali menjadi tanah ulayat kaum. Tetapi apabila tanah ulayat kaum tersebut telah didaftarkan dan dikeluarkan sertipikat hak miliknya, maka tanah tersebut hanya akan menjadi milik nama yang tercantum di dalam sertipikat tersebut. ${ }^{18}$

Dengan demikian dapat kita ketahui dengan jelas bahwa dalam hal subyek kepemilikan tanah, antara ketentuan yang ada dalam hukum adat Minangkabau dengan ketentuan yang terdapat di dalam UUPA terdapat perbedaan yang sangat prinsipil. Dari hasil analisis penulis diketahui bahwa sehubungan belum adanya aturan khusus yang mengatur secara rinci dan jelas tentang tata cara dan proses yang harus dilakukan untuk mendaftarkan tanah ulayat dari masyarakat hukum adat, khususnya tanah ulayat kaum di Minangkabau Sumatera Barat, maka dimungkinkan untuk melaksanakan pendaftaran tanah ulayat masyarakat hukum adat dengan memberikan alternatif subyek pendaftaran haknya antara lain :

18 Arpendi Datuk Tan Bagindo, Wawancara, tanggal 28 Juni 2018
1. Mendaftarkan atas nama semua anggota kaum yang berhak sebagaimana yang dicantumkan pada ranji (silsilah keturunan);

2. Didaftarkan atas nama seseorang selaku pihak yang ditunjuk oleh anggota kaum; atau

3. Didaftarkan atas nama Mamak Kepala Waris (MKW).

Namun secara yuridis alternatif ini nantinya akan dapat menimbulkan permasalahan dalam kaum yang bersangkutan dan akan mengakibatkan tanah tersebut dapat dialihkan kepada pihak lain. Apabila subyek hak atas tanah tersebut adalah mamak kepala waris atau salah seorang anggota kaum lainnya, dapat mengakibatkan sengketa antara mamak dan kemenakan atau anggota kaum lainnya, karena mamak dapat saja menjual tanah tersebut kepada pihak lain atau membalik namakan atan nama anak-anaknya.

Dari uraian diatas dapat Penulis simpulkan bahwa dalam proses pensertipikatan tanah ulayat kaum seharusnya yang menjadi subjeknya adalah seluruh anggota kaum dan diketahui oleh Mamak Kepala Waris. Dengan melibatkan seluruh anggota kaum maka akan meninimalisir terjadi sengketa dikemudian hari karena seluruh anggota kaum telah mengetahui dan mneyetujui untuk mensertipikatkan tanah ulayat kaumnya.

\section{Tidak adanya persetujuan dari Mamak Kepala} $\underline{W a r i s ~ d a n ~ A n g g o t a ~ K a u m ~ l a i n y a ~}$

Dalam pelaksanaan pendaftaran tanah ulayat kaum melalui program pendaftaran tanah sistematis lengkap yang dilaksanakan di Kecamatan Bungus Teluk Kabung, permohonan yang masuk diantaranya adalah permohonan dari salah salah anggota kaum yang mendaftarkan tanah ulayat kaum tanpa adanya persetujuan dari mamak kepala waris dan anggota kaum lainya. Karena permohonan tersebut cukup dengan membuat penguasaan fisik bidang tanah yang ditanda tangani oleh pemohon dan dua orang saksi. Dan ini 
tentunya sangat bertentangan dengan hukum adat di Minangkabau.

Berdasarkan wawancara penulis dengan Bapak Arpendi Datuk Tan Bagindo Ketua Kerapatan Adat Nagari Bungus yang menyatakan bahwa pada prinsipnnya sebagai ninik mamak beliau tidak setuju dengan program pendaftaran tanah sistematis lengkap karena tatanan pendaftaran tanah selama ini yang ada di Provinsi Sumatera Barat harus melalui prosedural artinya kalau tanah pusaka tinggi diketahui oleh mamak kepala waris dan anggota kaum lainya dengan melampirkan ranji, sehingga kalau keluar sertipikat baik atas nama salah satu kaum maupun atas nama Mamak Kepala Waris tidak ada permasalahan dikemudian hari karena seluruh anggota kaum sudah mengetahuinya. ${ }^{19}$

Dalam pendaftaran tanah tanah ulayat kaum melalui program pendaftaran tanah sistematis lengkap di Kecamatan Bungus Teluk Kabung ini persyaratan yang diminta sangat sederhana sekali sehingga banyak warga Bungus Teluk Kabung mengurus sertipikat tanah melalui program ini tanpa melibatkan Mamak Kepala Waris, Lurah dan Kerapatan Adat Nagari. Hal ini mengakibatkan hubungan Mamak dengan kemenakan mulai ada kesenjangan dan kurang harmonis.

Bapak Asril selaku Mamak Kepala Waris menyatakan keberatan atau tidak setuju akan program Pendaftaran Tanah Sistemtis Lengkap ini karena ada anggota kaumnya yang mendaftarkan tanah dan bangunan berupa rumah tempat tinggal, tanpa sepengetahuan beliau dan anggota kaum lainya. Keberatan tersebut disampaikan setelah petugas ukur melakukan pengukuran dilokasi, dan beliau melapor dengan memasukan surat keberatan ke kantor kelurahan dan dari pihak kelurahan disampaikan kepada Ketua Adjudikasi Badan Pertanahan agar permohonanya tidak diproses. ${ }^{20}$ Dari kasus tersebut Badan Pertanahan tidak akan mengeluarkan sertipikat hak atas tanah atau memasukan dalam kategori 3.

Sementara itu anggota kaum yang menduduki tanah ulayat kaum berupa rumah tempat tinggal merasa diuntungkan dengan program ini karena biaya yang dikeluarkan tidak ada atau gratis dan juga persayaratanya yang sangat mudah cukup dengan membuat permohonan dan membuat penguasaan fisik bidang tanah yang ditandatangani sendiri dan disaksikan oleh 2 (dua) orang. Dan pengumumanya pun sangat singkat sekali yaitu hanya 14 hari kalender. Jika selama pengumuman tidak ada sanggahan dari pihak lain maka sertipikat bisa dikeluarkan atas pemohon secara individu.

Jika kita bandingkan dengan pendaftaran tanah ulayat kaum secara sporadik permohonan tersebut selain dilengkapi dengan Kartu Tanda Penduduk juga dilengkapi dengan:

1. Ranji kaum

Ranji merupakan silsilah keturunan. Dari Ranji tersebut kita bisa mengetahui generasi sebelumnya yang ditarik dari garis keturunan Ibu. Kegunaan Ranji ini adalah ; Menyatakan garis keturunan Ibu; Menjelaskan kaitan atau perjalanan sako gelar kebesaran menurut jalur yang jelas; Menjelaskan pewarisan pusako (sawah, ladang dan lain-lain) yang merupakan milik bagi perempuan dan pengaturanya oleh laki-laki; Menjelaskan tali kekerabatan didalam dan diluar dari satu suku, baik didalam maupun di luarnya; Sebagai petunjuk atau pedoman bagi generasi sekarang dan yang akan datang guna mengenal kekerabatanya

2. Surat penguasaan fisik bidang tanah baik milik anggota kaum secara perorangan maupun milik kaum secara bersama dan

20 Asril selaku Mamak Kepala Waris, Wawancara, tanggal 26 Juni 2018 
surat tesebut ditanda oleh mamak kepala waris, penghulu suku dan Kerapatan Adat Nagari setempat dan saksi 2 (dua) orang (Formulir A lampiran surat KaKanwil BPN Propinsi SUMBAR No. 500/888/BPN2007 tanggal 08 Februari 2007)

3. Jika tanah ulayat kaum tersebut sudah diperuntukan untuk salah satu anggota kaum maka ditambah dengan surat persetujuan anggota kaum (Formulir B.1 lampiran surat KaKanwil BPN Propinsi SUMBAR No. 500/888/BPN-2007 tanggal 08 Februari 2007)

4. Dikuatkan dengan Surat Keterangan Kepala Desa/Lurah setempat.

Surat keterangan ini merupakan keterangan dari Kepala Desa/Lurah yang ikut membenarkan penguasaan fisik bidang tanah oleh pemohon dan membenarkan bahwa tanah tersebut dikuasai dan tidak dalam sengketa.

\section{Tidak dilibatkanya Kerapatan Adat Nagari}

Kecamatan Bungus Teluk Kabung terdapat dua Kerapatan Adat Nagari yaitu Kerapatan Adat Nagari Bungus dan Kerapatan Adat Nagari Teluk Kabung. Dengan adanya permohonan dari warga masyarakat Bungus Teluk Kabung yang mendaftarkan tanah ulayat kaumnya secara pribadi tanpa meminta persetujuan dari Mamak Kepala Waris dan anggota kaum lainya maka KAN Bungus telah menyurati pihak Badan Pertanahan Kota Padang dengan Nomor Surat 32/KANBgs/XI/2017 tanggal 06 November 2017 perihal mohon penangguhan sertipikat tanah. Badan Pertanahan Kota Padang telah membalas surat dari KAN Bungus tersebut dengan Nomor surat 1321/13.71/XI/2017 tanggal 10 November 2017 perihal mohon penangguhan sertipikat tanah.

Dalam suratnya tersebut Badan pertanahan menjelaskan peraturan Pendaftaran Tanah Sistematis Lengkap yaitu Peraturan Menteri Agraria dan Tata Ruang/ Kepala
Badan Pertanahan Nasional Republik Indonesia Nomor 12 Tahun 2017 Tentang Percepatan Pendaftarn Tanah Sistematis Lengkap yaitu Pasal 3 ayat (1) dan ayat (2), Pasal 19 ayat (1), ayat (4), Pasal 25 ayat (2) dan Pasal 26 ayat (1).

Dari surat Ketua Kerapatan Adat Nagari dan balasan surat dari Badan Pertanahan Kota Padang tersebut diatas dapat penulis simpulkan bahwa Badan Pertanahan Kota Padang dalam hal ini hanya mengacu pada Peraturan Mentri Agraria/Kepala Badan Pertanahan Nasional Republik Indonesia Nomor 12 Tahun 2017 tentang Pendaftaran Tanah Sistematis Lengkap tanpa melihat kepada tatanan hukum adat yang berlaku di Sumatera Barat karena dengan didaftarkanya tanah ulayat kaum oleh salah seorang anggota kaum akan dapat mempengaruhi keberadaan tanah ulayat di Minangkabau. Pola pemilikan tanah yang dianut oleh UUPA yang bersifat individual bertentangan dengan prinsip pemilikan tanah secara komunal (bersama) dalam masyarakat Minangkabau. Menurut hukum positif dinyatakan bahwa tanah yang telah didaftarkan dan disertipikatkan dengan sertipikat hak milik adalah menjadi milik nama yang tercantum dalam sertipikat tersebut.

Akibatnya tanah tersebut dengan mudah dipindahtangankan kepada pihak lain untuk selamanya atau dijual. Hal ini sangat bertentangan dengan konsep hukum Adat Minangkabau bahwa terhadap tanah ulayat tidak boleh diperjual belikan atau dipindahtangankan kepada pihak lain. Sebagaimana fatwa adat menyatakan dijua indak dimakan bali, digadai indak dimakan sando (dijual tidak bisa dibeli, digadai tidak bisa disandera). Pengalihan hak atas tanah ulayat kaum hanya dimungkinkan dengan cara gadai, namun menggadaikan tanah ulayat kaum kepada pihak lain hanya diperbolehkan dalam keadaan yang apabila;

a. Mayat tabujue tangah rumah (Mayat terbujur ditengah rumah). 
Dalam hal kematian dimana pihak keluarga tidak mempunyai dana yang cukup untuk membiayai penguburan.

b. Gadih gadang take balaki (Gadis dewasa belum bersuami).

Bila kemenakan perempuan belum bersuami, hal ini sangat merisaukan keluarga, apalagi kalau anak tunggal, keluarga ketakutan karna bisa punah. Bila perlu dicari jemputan untuk menjadi suami dengan memberi uang jemputan

c. Mambangkik batang tarandam (Membangkit batang terendam)

Bila gelar pusako sudah lama "balipek" karena tidak cukup biaya untuk upacara batagak penghulu maka boleh menggadai.

d. Rumah gadang katirisan atau pautuik malu diri (Rumah gadang yang bocor atau penutup harga diri).

Bila salah satu anggota kaum berutang yang belum dapat dilunasi maka dari pada malu seluruh keluarga, apa boleh buat terpaksa menggadai. Begitu pula bila rumah gadang sebagai rumah milik bersama, ternyata sudah rusak seperti bocor atau sudah lapuk, maka boleh menggadai untuk keperluan perbaikan itu.

Pada masyarakat di Kecamatan Bungus Teluk Kabung masih terdapat pro dan kontra dalam hal pendaftaran tanah "pusako tinggi" (ulayat kaum), sebahagian berpendapat ada yang setuju dengan pendaftaran dan pensertipikatan tanah ulayat kaum dan ada yang tidak setuju jika tanah pusaka tinggi (ulayat kaum) disertipikatkan. Bahwa dengan melakukan pendaftaran dan pensertipikatan tanah maka kita telah ikut serta menyukseskan program pemerintah dan disamping itu tanah yang telah disertipikatkan akan memiliki nilai ekonomis yang tinggi nantinya. hak milik atas tanah menurut adat sudah jelas, dan tidak perlu lagi diadakan pembuktian tertulis seperti sertipikat.

Di samping itu pendaftaran tanah menyebabkan perubahan sifat hak ulayat dari hak komunal menjadi hak individu. Perubahan tersebut dapat merugikan anggota kaum, sebab apabila tanah tersebut didaftarkan atas nama Mamak Kepala Waris atau salah seorang anggota kaum timbul kekhawatiran tanah tersebut nantinya akan dialihkan, dijual atau digadaikan ke bank. Problematika Hukum Pendaftaran tanah ulayat kaum adalah terdapatnya konflik antara kebijakan Pemerintah dalam melaksanakan program pendaftaran tanah di Indonesia untuk mendapatkan kepastian hukum dan kepastian hak atas tanah, sementara dilain pihak hakekat pendaftaran tanah ulayat kaum akan "mengaburkan/babkan mengbilangkan" kepastian hukum tanah ulayat tersebut, karena menjadi kepemilikan individual.

Selain itu dari hasil penelitian dilapangan juga dapat dinyatakan bahwa apabila tanah ulayat kaum (pusako tinggi) didaftarkan dan disertipikatan maka akan mempengaruhi keberadaan tanah ulayat kaum tersebut, karena menurut mereka semua anggota kaum menurut adat Minangkabau wajib memelihara dan menjaga keberadaan tanah agar tetap utuh dan dapat diwariskan kepada generasi yang akan datang dalam keadaan utuh pula.

Menurut ketentuan hukum adat Minangkabau yang berhak menjadi ahli waris dari harta pusaka kaum adalah kemenakan atau anak dari saudara perempuan. Sebagaimana fatwa adat menyatakan;

"birik-birik tabang kasamak, tibo disamak. turun kahalaman, binggok ditanah bato, dari niniak turun kamamak, dari mamak kakamanakan, pusako tetap baitu juo, sako jawek bajawek, pusako turun tamurun"

(birik-birik terbang kesemeak, dari semak turun kehalaman, hingga ditanah bata, dari nenek turun kemamak,dari mamak kekemanakan, pusaka tetap begitu juga, sako/gelar sambut-bersambut, harta pusak turuntemurun). 
Bahwa hukum waris adat Minangkabau menganut asas keutamaan, maksudnya adalah selama yang mempunyai hubungan kekerabatan terdekat masih ada maka yang lain belum akan dapat menerima warisan. Sebab menurut adat Minangkabau ahli waris adalah orang yang patut menerima warisan menurut keturunan yang asli, yaitu keturunan menurut tali ibu (matrilineal). ${ }^{21}$ Setiap anggota kaum di Minangkabau mempunyai kewajiban untuk menjaga dan memelihara keutuhan dan keberadaan tanah ulayat kaumnya, sehingga generasi berikutnya dapat menikmatinya.

Tanah ulayat kaum yang telah didaftarkan dan dikeluarkan sertipikatnya, apabila terjadi pewarisan (peristiwa hukum) maka ahli warisnya adalah kemenakan, alasannya karena kemenakan dianggap sebagai penerus dari kelangsungan keberadaan kaum atau kekerabatan matrilineal mereka. Sebagaimana yang telah disebutkan di atas bahwa bagi masyarakat matrilineal Minangkabau warisan diturunkan kepada kemenakan atau anak saudara perempuan, namun kemenakan laki-laki dan perempuan yang berhak menerima warisan tersebut memiliki kewenangan yang berbeda. Kemenakan laki-laki mempunyai hak mengusahakan, sedangkan kemenakan perempuan berhak memiliki.

Harta Pusaka tinggi sebagai harta milik kaum dalam hal pengelolaan, pemanfaatan serta pengawasan dikuasakan sepenuhnya oleh kaum tersebut kepada mamak. Peran mamak tidaklah sebagai "the owner" tapi hanya sebagai manager yang harus bertanggungajawab kepada kaumnya sebagai pemilik. Sebagai mamak ia hanya mewilayah, adat sangat mencela seorang mamak yang tidak "menukuak jo manambah, bersikuat menghabiskan". Peranannya sebagai pengelola akan berakhir apabila dia telah tidak mampu lagi karena usia

${ }^{21}$ Suhaili selaku Ketua Kerapatan Adat Nagari Teluk Kabung Kecamatan Bungus Teluk Kabung, Wawancara, tanggal 26 Juni 2018 dan kesehatan yang mulai menurun atau meninggal dunia dan akan muncul manager baru, baik dari generasi yang sama atau dari generasi berikutnya.

Dalam hal pewarisan hukum adat Minangkabau menganut asas keutamaan, maksudnya adalah selama yang mempunyai hubungan kekerabatan terdekat masih ada maka yang lain belum akan dapat menerima warisan. Sebab menurut adat Minangkabau ahli waris adalah orang yang patut menerima warisan menurut keturunan yang asli, yaitu keturunan menurut tali ibu (matrilineal). Oleh karena itu dalam sistem kekerabatan Minangkabau dikenal dua lapisan tali kekerabatan yaitu tali kekerabatan yang dekat dan garis kekerabatan yang jauh. Jauh dan dekatnya hubungan kekerabatan di Minangkabau dalam adat digambarkan dengan istilah "nan satampok, nan sajangka, nan sabeto dan nan sadapo" (yang setampar, yang sejengkal, yang sehekto dan yang sedepal).

Jadi selama waris "nan satampok" masih ada maka waris nan sajangka tidak akan memperoleh warisan harta pusaka, begitu selanjutnya. Selain itu jauh dekatnya ahli waris juga diukur dari hubungan antara mamak dan kemenakannya. Dalam hal ini dikenal dengan kemenakan yang bertali darah dan kemenakan yang bertali adat, lapisan ketiga yaitu kerabat bertali budi dan lapisan terakhir yaitu kerabat bertali emas. Selama kemenakan yang mempunyai hubungan kekerabatan terdekat denagan mamak masih ada maka yang lain belum akan dapat menerima warisan.

Kemudian di samping itu menurut ajaran adat Minangkabau yang berhak atas kepemilikan tanah pusaka tinggi adalah kaum perempuan (bundo kanduang), hal ini disebabkan karena fungsinya sebagai penyambung keturunan dan kekerabatan matrilineal. Atas dasar hal tersebut anak perempuan berperan sebagai pemegang harta pusaka yang dalam masyarakat Minangkabau dikenal dengan istilah "ambuan puro aluang 
bunian" (pemelihara dan pemegang kunci harta kekayaan kaumnya) dan selain itu kaum perempuan dekenal juga sebagai "limpapeh rumah nan gadang".

Sedangkan kaum laki-laki adalah sebagai pemimpin dalam kaumnya dan mengatur pemanfaatan, pengelolaan tanah pusaka tersebut, untuk menjaga dan memeliharanya adalah kewajiban semua anggota kaum. Tanah ulayat ini merupakan tanah yang dicadangkan untuk memenuhi kebutuhan anak kemenakan (komunitas masyarakat adat) baik untuk masa sekarang maupun untuk masa yang akan datang, sehingga tanah (ulayat) benar-benar ditujukan untuk kesejahteraan komunitas masyarakat adat serta cucu pada saat sekarang maupun masa yang akan datang.

Harta pusaka merupakan amanah yang diterima dari orang tua-tua dan nenek moyang yang harus dijaga dan diteruskan kepada generasi selanjutnya sesuai dengan ketentuan hukum adat yang berlaku. Setiap orang Minangkabau mempunyai tiga macam kewajiban, yaitu kewajiban masa lampau, kewajiban masa kini dan kewajiban untuk masa yang akan datang. Kewajiban masa lampau maksudnya bahwa generasi dahulu wajib mewariskan tanah ulayat kepada generasi yang sekarang, dan generasi sekarang wajib menjaga keutuhan tanah ulayat yang diwarisi tersebut dan Tanah ulayat tidak boleh dipindah tangankan atau dijual kepada pihak lain serta harus dipertahankan keberadaannya dan wajib untuk mewariskan kepada generasi yang akan datang dalam keadaan utuh.

Barang siapa yang melanggar ketentuan mengenai sistem penguasaan dan dalam pemanfaatan tanah ulayat tersebut ada sanksinya, sebagaimana menurut adat Minangkabau terkena sumpah pasatian, yaitu "kaateh indak bapucuak, kabawah indak baurek, ditangah-tangah digiriak kumbang, bak karakoke diateh batu, hiduaik anggan mati indak amuab" (keatas tidak ada pucuk, kebawah tidak ada uratnya, ditengah-tengah dimakan kumbang, seperti kerakap tumbuh dibatu, mati enggan mati tidak mau). Sehingga orang yang kena sumpah pasatian ini hidupnya merana sepanjang masa.

Dari uraian diatas nampak bahwa telah terjadi suatu pergeseran nilai terhadap ketentuan-ketentaun yang merupakan ciri khas pada sistem kekerabatan matrilineal bahwa harta pusaka diwariskan kepada kemenakan (keponakan) atau anak dari saudara perampuan. Memperhatikan pelaksanaan pendaftaran tanah melalui program pendaftaran tanah sistematis lengkap di Sumatera Barat, khususnya di Kecamatan Bungus Teluk Kabung telah tejadi penyimpangan aturan adat. Hal ini disebabkan karena mereka menganggap bahwa tanah pusaka tinggi atau tanah ulayat kaum yang telah didaftarkan dan disertipikatkan tersebut telah menjadi hak milik pribadi mereka menurut hukum perdata.

\section{KESIMPULAN}

Berdasarkan penelitian yang telah dilakukan Penulis dalam pelaksanaaan Pendaftaran Tanah Ulayat Kaum Melalui Program Pendaftaran Tanah Sistematis Lengkap di Kecamatan Bungus Teluk Kabung, maka dapat diambil beberapa kesimpulan.

Pelaksanaan Pendaftaran Tanah Ulayat Kaum Melalui Program Pendaftaran Tanah Sistematis Lengkap di Kecamatan Bungus Teluk Kabung hanya 9,6 \% yang bisa diterbitkan sertipikat hak atas tanahnya (Kategori 1) yaitu sebanyak 1.052 bidang tanah dari target 10.100 bidang di Kecamatan Bungus Teluk Kabung sebagaimana yang sudah ditentukan oleh pemerintah dan yang tidak bisa ditebitkan sertipikatnya sebanyak 12.859 bidang tanah (Kategori 3). hal ini dikarenakan beberapa kendala-kendala dalam pelaksanaan pendaftaran tanah ulayat kaum tersebut. 
Kendala-kendala yang timbul dalam Pelaksaanaan Pendaftaran Tanah Kaum Melalui Program Pendaftaran Tanah Sistematis Lengkap di Kecamatan Bungus Teluk Kabung diantaranya adalah mengenai subyeknya yaitu atas nama siapa sertipikat itu didaftarkan apakah atas nama Mamak Kepala Waris, atas nama salah satu anggota kaum atau atas nama Mamak Kepala Waris beserta anggota kaum karena pada umumnya dilapangan banyak yang mendaftarkan atas nama salah seorang anggota kaum tanpa diketahui oleh Mamak Kepada Waris beserta anggota kaum lainya. Kendala yang lainya adalah tidak dilibatkannya Mamak Kepala Waris, dan Kerapatan Adat Nagari dalam proses pendaftaran tanah tersebut. 


\section{DAFTAR KEPUSTAKAAN}

Amir MS. Adat Minangkabau Pola dan Tujuan Hidup Orang Minang, Mutiara Sumber Widya. Jakarta,1997.

Boestami, Sjafnir Abu Naim dan Rosnida M Nur LC, Kedudukan dan Peranan Wanita Dalam Kebudayaan Suku Bangsa Minangkabau, Esa Padang, 1992.

Mujiono, "Hukum Agraria", Liberty, Yogyakarta 1992.

//harianhaluan.com/mobile/detailberita/66777/ptsl-bukan-bagibagi-tanah-sumbar-dijatah65000-sertifikat\&ei=KOf5X1Fl\&lc=id- di akses tanggal 8 November 2017, pukul 09.30 WIB

persadanews.com/atr-bpn-kota-padang-dapatkan-20-000-kuota-ptsl-dari kementerian-agrariadan-tata-ruang-badan-pertanahan-nasional/ di akses tanggal 8 november 2017, pukul $09.40 \mathrm{WIB}$

Santoso, Urip, "Hukum Agraria”, Cet 1, Kencana Prenada Media Group, Jakarta, 2012.

Soemitro, Ronny Hanitjo, Metode Penelitian Hukum dan Jurumetri, Ghalmis Indonesia, Jakarta.

Soeprapto, MFI, Ilmu Perundang-Undangan: Jenis, Fungsi, Dan Materi Muatan, Kanisius, Yogyakarta, 2010.

Syarifuddin, Amir, Pelaksanaan Hukum Kewarisan Islam Dalam Lingkungan Adat Minangkabau, Gunung Agung, Jakarta, 1984. 